\title{
Planning a More Humane City: Student Expectations Concerning Bicycle Use and Transportation in Zagreb
}

\author{
Aleksandar Lukić, Vedran Prelogović, Stanko Rihtar
}

\begin{abstract}
Researches indicate that the use of bicycles as a means of transportation and form of recreation is increasing in cities in the world's developed countries, and that it brings with it a humanization of urban spaces and improved quality of life. Bicycle use has rarely been the topic of scholarly interest in Zagreb or Croatia as a whole, especially among student population. Therefore, a survey was conducted among students of the University of Zagreb to gauge their expectations of bicycle use and other forms of transport in Zagreb. The questioning encompassed 238 student cyclists and 359 student non-cyclists, selected by a combination of representative and focused sampling. The results point toward significant statistical discrepancies between the two student groups in their manner of using bicycles and other means of transport. Furthermore, student expectations of the city government encompass, besides anticipated measures to improve the cycling infrastructure, a series of other measures, such as, for example, subsidies for bicycle purchases and the introduction of a public bicycle sharing system. The conclusion includes six proposals for activities aimed at increasing the number of bicycle users to be undertaken by the city government and other interested parties.
\end{abstract}

Key words: bicycle modal share, urban planning, Zagreb

\section{Planiranje humanijeg grada: očekivanja studenata o korištenju bicikla i prometa u Zagrebu}

Istraživanja ukazuju da je korištenje bicikla kao prijevoznog sredstva i oblika rekreacije sve učestalije u gradovima razvijenih zemalja svijeta, te da pridonosi humanizaciji gradskih prostora i podizanju kvalitete življenja. U Zagrebu i Hrvatskoj biciklistički promet i korištenje bicikla rijetko su bili predmetom znanstvenog interesa. Stoga su anketom istražena očekivanja studenata Sveučilišta u Zagrebu prema korištenju bicikla i ostalim oblicima prometa u Zagrebu. Ispitano je 238 studenata biciklista i 359 studenata nebiciklista, odabranih kombinacijom reprezentativnog i namjernog uzorka. Rezultati upućuju na značajne statističke razlike između dvije studentske skupine u načinu korištenja bicikla i ostalih prijevoznih sredstava. Nadalje, studentska očekivanja od gradskih vlast, uz očekivane mjere poboljšanja biciklističke infrastrukture, obuhvaćaju i niz drugih, primjerice subvencije za kupnju bicikla i uvođenje sustava javnih gradskih bicikala. U zaključku članka navodi se šest prijedloga za aktivnosti gradskih vlasti i ostalih zainteresiranih strana u podizanju broja korisnika bicikla.

Ključne riječi: biciklistički promet, urbano planiranje, Zagreb 


\section{INTRODUCTION}

The need for the harmonious development of a city and its functional, social and morphological components has imposed itself as the pre-eminent paradigm in urban planning at the onset of the twenty-first century. Cities in the world's developed countries, such as Copenhagen (Gehl et al., 2006; Gehl, 2010), have taken the lead in implementing new ideas and technologies based on the results of research, with the aim of raising the quality of life and humanizing the urban space. ${ }^{1}$ A city's physical space must be vigorous, safe, sustainable and healthy for all residents and functions (Gehl, 2010). In this context, the application of knowledge and research results assumes first-class importance. The introduction of an integrated transportation system which unifies and balances the use of motor vehicles, public transport, cycling and pedestrian traffic comes to the fore among the aforementioned innovations in the planning of urban zones.

Research has shown that bicycle use as a means of transportation and a form of recreation is becoming more common in many cities in the world's developed countries. Thus, for example, in Copenhagen $37 \%$ of all daily travel inside the city (the commute to work, college and school) is done by bicycle. A similar example is Amsterdam, in which as much as $54 \%$ of daily travel is done by bicycle! To these well-established examples of cyclist cities we may add many German and Swedish cities, although their percentages of use lag behind considerably, while initiatives in this direction have been launched in London, Paris, Barcelona and elsewhere (Pucher et al., 2010). Thus, the positive experiences of many European cities in the integration of bicycles into their urban transport systems should spur the efforts of city governments, the academic community and non-governmental organizations to increase bicycle use as a means of transportation and a form of recreation.

In recent years, Zagreb has also been confronted with growing pressure on its space, including the city's transportation system, which is being altered and adapted to new economic and social demands by public and private exponents. Increased bicycle use is imposing itself as one of the most acceptable solutions - as confirmed by the aforementioned experiences of many European cities. The bicycle as a means of transportation has a positive impact on individual health, for it does not pollute the environment nor create noise as motor vehicles do, the cycling infrastructure occupies much less space (Pucher and Buehler, 2008), and one may rightfully deem it a competitive urban transport means over small and medium distances.

In terms of its relief, the territory of the city of Zagreb is very well-suited to bicycle use. For Zagreb is a rather lowland city, with most of the narrower urbanized zone at elevations between 110 and $125 \mathrm{~m}$, with only portions of neighbourhoods north of the main urban thoroughfares (Ilica, Vlaška and Maksimirska) higher than elevations of $130 \mathrm{~m}$ (Bertić, 1994), which considerably eases the usability of bicycles as a means of transportation.

In Zagreb and Croatia as a whole, bicycle use has rarely been the topic of scholarly interest. The objective of this work is to contribute to scholarly knowledge on the expectations of students of the University of Zagreb concerning bicycle use as a means of transport and a form of recreation. Besides this principal objective, the following individual aims and tasks arise: 
- To ascertain the number of bicycle users among the students of the University of Zagreb;

- To ascertain (statistically significant) discrepancies between the groups of students who use and students who do not use bicycles as a means of transport and a form of recreation;

- To contribute to the theoretical and methodological foundations of research.

The crucial questions that shall be answered in this work are:

- How often do students use bicycles and other forms of transport as their means of transport?

- How satisfied are students with Zagreb's cycling infrastructure?

- What should the city government do to improve the cycling infrastructure (bikeways and bicycle parking) in Zagreb?

- What could the city government do to encourage greater bicycle use among students in Zagreb?

The achievement of the primary and individual research objectives and tasks and the answers to the above questions have been obtained by analysis of the recent scholarly literature and sources of data, while the primary research tool in this work, the survey, constitutes the methodological instrument.

\section{GROWING AUTOMOBILIZATION AND PLANNING A SUSTAINABLE CITY TRANSPORTATION SYSTEM}

The increasing problems in transportation system planning and the question of sustainable development, combined with the simultaneous need for a higher quality of life and the humanization of urban space, are deemed the crucial issues of urban development in the world's developed countries. Research has shown that the constant growth of personal motor vehicle traffic in urban zones inevitably foments numerous problems: traffic congestion, increased noise, air pollution caused by exhaust emissions, increased traffic accidents, an increased percentage of overweight individuals, etc. (Blanco et al., 2009; Rybarczyk and $\mathrm{Wu}, 2010$; Pucher et al., 2010). Over and above these problems, in the urban cores of European cities oriented toward motor vehicle transport there is also the matter of reduced public spaces due to the need to resolve stationary traffic (reduction and disappearance of pedestrian zones, narrowing of sidewalks, construction of access ramps to basement garages). European cities generally emerged in an entirely different spatial, temporal and technological environment than that of contemporary times, in the pre-automobile era, so their traditional urban cores, despite innovative solutions and scientific and technological advances, have little possibility of physical alteration. All of these factors lower the quality of life in cities (Blanco et al., 2009) and prompt the consideration and formulation of sustainable urban traffic systems (Plaut, 2009; Rybarczyk and Wu, 2010).

The city of Zagreb is also confronted with these problems of organization of its traffic system, which largely follows from the fact that in less than fifteen years, the number of 
registered motor vehicles has more than doubled (1995 - 176.970; $2000-284.308 ; 2008$ - 414.353) (Source: 1,2 and 3)! An increasingly accepted view is that "the traffic volume in the road system [of Zagreb - authors' note] ... has grown to such dimensions that it surpasses the capacity of the system, which is today completely saturated" (Pološki et al., 2008: 372). Thus, the aforementioned negative consequences associated with the growth of individual automobile use are becoming increasingly visible: "an increasing number of vehicles in the city centre, greater traffic congestion, greater air pollution caused by exhaust emissions, much more noise and pollution in the city centre (which) leads to poorer residential conditions in the city centre" (Golubić and Kolar, 2006: 158).

For example, measurements of the noise level at two typical locations, on a thoroughfare in the wider city core (Klaićeva street) and Slavonska avenue near Cvjetno naselje, which has a higher traffic volume, showed impermissibly equivalent noise levels throughout the day and night (Dragčević et al., 2006). Knowing that approximately $81 \%$ of the sources of noise is due to traffic, out of which $50 \%$ accounts for road traffic, the reason for seeking to reduce the share of motorized traffic in the city becomes more apparent (Dragičević et al., 2006). Besides noise "pollution," Zagreb has also not been spared the constant growth of motor vehicle exhaust pollution, despite technological progress in emissions reduction in modern motor vehicles and their regular inspection (Golubić and Kolar, 2006). Besides these direct negative repercussions ensuing from the growth in the share of motor vehicle use, citizens are becoming increasingly aware and sensitive to the other consequences of motorization, such as urban planning projects which reduce public space due to the growing need for the construction of parking spaces or access to underground garages. This is particularly notable in the city core, in which even the city's traffic documents foresee the restriction of personal motorized traffic (City of Zagreb Traffic Study, 1999). At the same time, despite expansion of the tramcar network and upgrading of its rolling stock, public bus and tramcar transportation has recorded reduced numbers of passengers conveyed since the beginning of the 1990s (Fig. 1).

The Zagreb city government is aware of these problems in the urban transport system, which are largely a consequence of the high share of personal motor vehicle use, at least judging by the city's most important physical planning documents. For example, the Decision on Ratification of the Urban Master Plan, explicitly includes the statement that "the long-term objective ... [is] to ensure that a minimum of two thirds of all daily travel proceeds in public transit and non-motorized forms of travel" (as published in the city's official bulletin, Službeni glasnik Grada Zagreba, 2007). The City of Zagreb Traffic Study of 1999 outlined the creation of a sustainable transportation system which would secure improvement of its cost effectiveness, protect the environment from the harmful effects of traffic, increase passenger safety and increase the accessibility and ease of travel to transportation facilities. To achieve these objectives, measures were proposed such as enhancement of public transportation capacity and the level of services through financially feasible modernization, securing greater accessibility to the transit network and means of transportation, reduction of personal automobile use, increasing the number of parking lots for motor vehicles, improvement of conditions for non-motorized traffic, increasing traffic safety and reduction of noise and air pollution. 


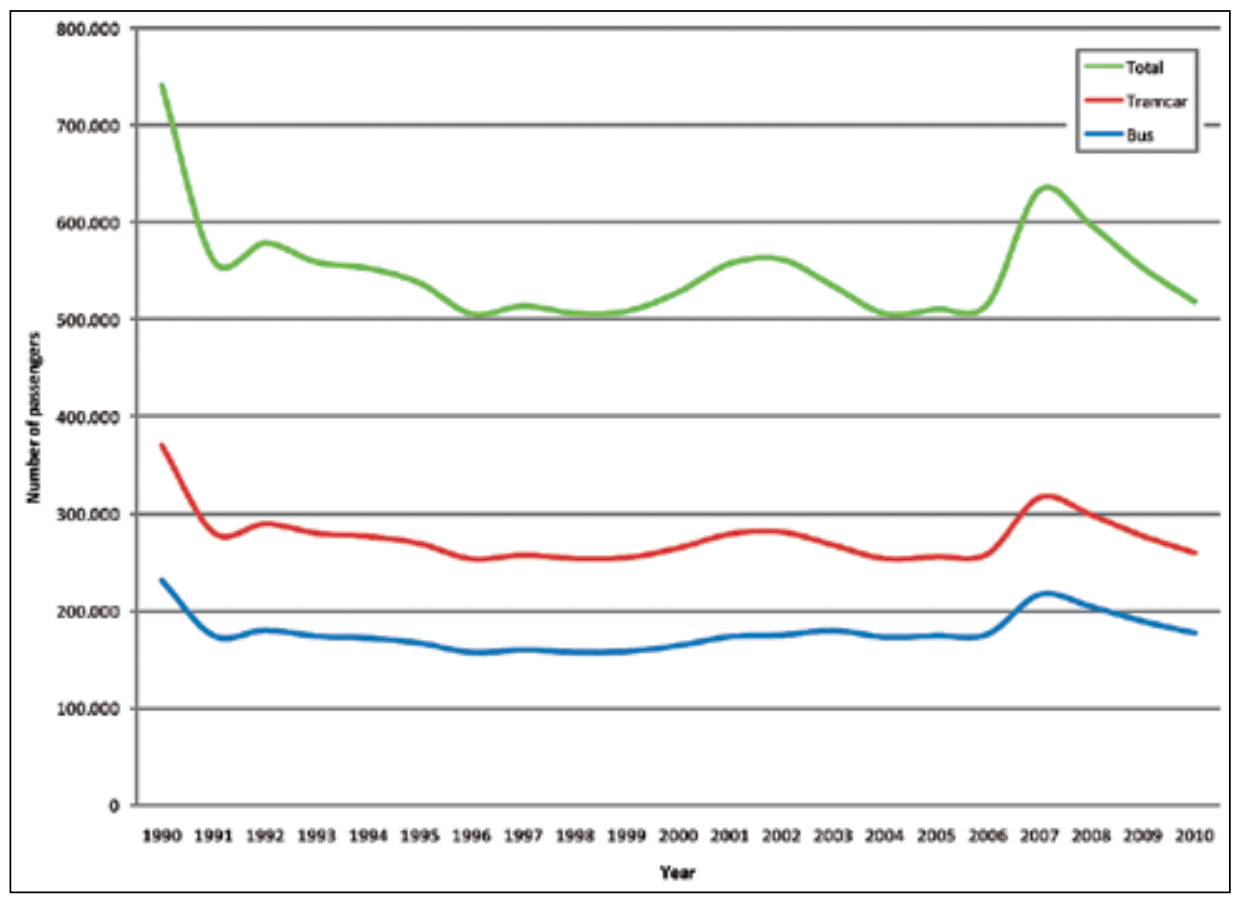

Fig. 1 Number of passengers conveyed by tramcar and bus in Zagreb (1990-2009)

Sl. 1. Broj prevezenih putnika tramvajem i autobusom u Zagrebu (1990-2009.)

Source: $1,2,3$ and 4

Despite such objectives, experts have predicted that the share of motor vehicle traffic in Zagreb will grow from $50.3 \%$ in 1998 to $66 \%$ in 2020 , while at the same time the share of motorized public transit will decline from $49.7 \%$ to $34 \%$ (City of Zagreb Traffic Study, 1999)!

\section{BICYCLE USE AS AN INTEGRAL COMPONENT OF A SUSTAINABLE URBAN TRANSPORTATION SYSTEM}

In the search for a balanced, safe and effective transit system which integrates all forms of transportation, assigns them equal value and minimizes mutual conflicts, besides advancement of public transit, the attempts at higher bicycle use are apparent, even to the extent of its integration into the urban public transportation system (public bicycle sharing system/bike-share and intermodal transport). In this regard, Dutch, Danish and certain German cities in which the share of bicycle use has attained very high levels (even as much as $40 \%$ of all travel in a given city) are cited as examples of sound practices. Research has shown that the trend to increase bicycle use follows from a series of factors: lifestyle changes, growing individual awareness of the importance of bicycles, the actions of city governments which invest considerable funds in the cycling infrastructure and promotion of bicycle use among people regardless of gender, educational levels and age, and so forth 
(Pucher and Buehler, 2008). Furthermore, this is a result of the knowledge that the everyday or frequent use of bicycles to travel to work, school, or college, or to go shopping or for recreational purposes increases the daily mobility of individuals, reduces air pollution and noise caused primarily by motor vehicle traffic, and positively impacts health (Cycling in London, 2008; Gatersleben and Haddad, 2010; Pucher and Buehler, 2008; Pucher et al., 2010). Bicycle use, given its price, is available to almost everyone, and in comparison with other forms of transportation, the bicycle (both in motion and at rest) occupies very little space. In other words, research confirms that the bicycle, alongside walking, truly may be deemed the environmentally, socially and economically most sustainable form of transportation (Plaut, 2009; Pucher and Buehler, 2010). Often traditions, culture, relief and climatic features are cited as obstacles to bicycle use (Nankervis, 1999), but the experiences of the already mentioned European and other states have shown that, although relevant, these factors need not be crucial. Namely, the measures taken by national and city governments within the sphere of physical planning, transport and economic policies largely influence to rates of bicycle use, particularly as a form of transportation in cities (Pucher and Buehler, 2008; Pucher and Buehler, 2006).

In Zagreb as well, the bicycle is increasingly recognized as one of the potential means of transportation in the formation of a sustainable traffic system. In the aforementioned physical planning documents and studies, non-motorized forms of transportation are underscored as one of the measures to achieve the long-term objective of reducing individual automobile traffic. During the past several years, the trend of establishing a cycling infrastructure has been notable, particularly the demarcation of bicycle lanes (on carriageways) and bikeways, which today cover a length of approximately $190 \mathrm{~km}$. The urban master plan stipulates the standards for construction of bicycle lanes and bikeways (2007). ${ }^{2}$ Additionally, the City of Zagreb has joined the European cleaner urban transport initiatives: CIVITAS I (2002-2006), CIVITAS II (2005-2009), CIVITAS+, and it also participated in the consortium of cities which prepared the draft CIVITAS-ELAN project, in which it also participates (Bedenko, 2008). The objectives of these projects are aimed at the formation of a more intelligent city transportation system in which a more important role will also be assumed by bicycle use. The activity of non-governmental organizations in the popularization of bicycle use for everyday personal transport and as a form of recreation has also been evident (Udruga bicikl and Zelena akcija - bicycle promotion associations, environmental protection groups).

Nevertheless, despite these positive steps forward, we would argue on the basis of regular bicycle use as a transport mean in Zagreb, that it is still not treated as an equal and important means of transport, and that bicycle use is not perceived as an integral component of the city's traffic system. For example, bikeways, although their length has been increased, are not linked into an overall network that would allow for rapid, safe and efficient bicycle use as a means of transport. At some locations, their use is questionable due to insufficient lane width and conflicts with other means of transport. The problem is particularly notable in the city centre. The number of bicycle parking facilities, although higher, is still insufficient. An urban traffic study conducted by the environmental protection association Zelena akcija (2010) highlights similar problems.

Even the scholarly community has thus far not shown any significant interest in the 
problems surrounding bicycle use. For example, an examination of the two most comprehensive databases of domestic scholarly journals and works by Croatian scholars yielded only a few publications and articles on bicycle use as a means of transport (Halgota, 2010; Missoni and Kern, 2007). ${ }^{3}$ Although two significant scientific conferences were held on the problems surrounding the development of Zagreb and its transport system, there was no presentations focused nor dedicated exclusively to bicycle use in Zagreb, even though it is mentioned in several papers. ${ }^{4}$ Scientific research into bicycles in Croatia is also impeded by the fact that there are no official statistics on bicycle use, neither as a means of transport nor as a form of recreation. In European Union member states, information on the frequency of bicycle use as a means of transport is gathered in censuses, and this will be an obligation in Croatia for the 2011 census. This will provide relevant data that can then be compared to other European Union member states. Furthermore, according to the information available to us, so far no specific, systematic counts of cyclists in Zagreb and other Croatian cities have been conducted (either manually or through some more technologically modern, automated method). The counting of cyclists is a standard method in many European and world cities, particularly in those in which the bicycle has in practice been accepted as a vital means of transport or in cities attempting to increase its share in traffic. The only statistic available to these authors is that ascertained over ten years ago in the City of Zagreb Traffic Study by a survey according to which "other forms of travel such as bicycles and taxis play only a minor role with less than $1 \%$ of all travel" (Prometna studija Grada Zagreba, 1999).

As a result of the aforementioned, the City of Zagreb, within the framework of the international project called PRESTO - Promoting Cycling for Everyone as a Daily Transport Mode, has planned for survey research of the student population (the project's target group) in order to estimate the share of students who use bicycles in Zagreb and contribute to the formulation of measures to double the number of students using bicycles in Zagreb by gathering scientific data on their habits, opinions and expectations concerning bicycle use. This article presents a selection of the results of that research: data on the share of students who use bicycles, habits in the use of transport means in Zagreb, an evaluation of the existing cycling infrastructure and the expectations from the city government.

\section{METHODS}

Who is a cyclist? This arose as the key methodological question prior to conducting the survey. This apparently straightforward question is particularly important both to quantify the share of cyclists among students and to scrutinize expectations, for it is justifiably possible to assume that the expectations of cyclists and non-cyclists on the bicycle as a means of transport and form of recreation, and on urban transportation in generall, are to some extent different because of their different experiences in use, which has been confirmed by foreign research (Gatersleben and Haddad, 2010; Cycling in London, 2008:56). The latter, based on an analysis of a high number of studies on cycling, explicitly states that the most common segmentation is either that based on bicycle use (cyclists vs. non-cyclists) or that based on gender. Additionally, foreign research also often utilizes the number of kilometres travelled by bicycle per resident annually (Pucher and Buehler, 2008), while the national transportation ministries are cited as sources. 
As already stated, domestic scientific research into this problem is scant and it does not deal with this apparently simple question. But the complexity of the question who is a cyclist?, particularly in the context of ascertaining the share of cyclists in the total population, has also been confirmed by foreign research (Gatersleben and Haddad, 2010). Moreover, in most research, which largely makes use of national statistics agencies, European Union statistics agencies and/or national transportation ministries, no use is made of data on the share of cyclists, but rather on the bicycle share of trips or bicycle modal share. This is certainly a more precise determination, which Croatia will obtain with the 2011 population census. $^{5}$

Dictionaries of the Croatian language specify that a cyclist [biciklist] is "one who rides a bicycle" (Hrvatski jezični portal, hjp.srce.hr, 2010). Foreign research into habits and opinions concerning bicycle use generally enhance this simple definition by adding variables on frequency or regularity of use (Gatersleben and Haddad, 2010). Therefore, we expanded the initial lexical definition for the needs of this research and specified a cyclist "as one who regularly rides a bicycle". Logically the question arose as to what, in fact, 'regularly' means. How many times weekly/monthly/annually should one ride a bicycle for it to be deemed regular? The foreign research consulted here was not unanimous, for it does not offer an unified stance. However, a more important lesson is that the aforementioned periods are dependent upon bicycle use habits in specific cultures: thus, for example, in some research conducted in the cyclist Netherlands (Buehler and Pucher, 2010), the period is a shorter time (a week), while one research project in the United Kingdom, in which the share of bicycle travel is almost ten times less than in the Netherlands, a period of two months was used (Gatersleben and Haddad, 2010). Therefore, determination of frequency and regularity is obviously a convention, but based on trends in relation to bicycle use in a given culture.

For this research, with regard to foreign examples, our own previous knowledge and many years of experience in bicycle use as both a means of transportation and as a form of recreation, the following working definitions have been formulated: those respondents who ride their bicycles a minimum of once monthly on average (excepting possibly the colder period of the year), either as a means of transport or for recreational purposes, are deemed cyclists; respondents who ride bicycles less than once monthly on average, whether as a means of transport or for recreation purposes, are deemed non-cyclists.

The research was conducted by means of a survey with a combination of representative and focused samplings of students of the University of Zagreb, from 14 to 18 June 2010 and it encompassed 600 respondents (1.02\% of all University students). ${ }^{6}$ The representative sampling encompassed 450 students, while the focused sampling encompassed 150 students who regularly use bicycles (cyclists). The combination of representative and focused samplings secured a relevant assessment of the share of students of the University of Zagreb who use bicycles, while simultaneously facilitating a more advanced statistical analysis of data on student cyclists who with reference to their expected small share would not have been methodologically justified in the representative sampling. The division of respondents into two groups with regard to the regularity of their bicycle use (cyclists and non-cyclists) allowed for the formulation of two questionnaires, each intended for specific target group. Both questionnaires consisted of closed (responses suggested, ranking) and 
open questions, so that the respondents were given greater freedom in responding.

The representative sampling of the student population of the University of Zagreb was stratified on the basis of two variables: enrolment in a given university faculty and gender. The first variable, faculty enrolment, i.e. major course of study, is often used in the formation of representative samplings to survey student opinion. Additionally, one may assume that the physical location of the university faculty is a significant variable which may influence the decision to use a bicycle (accessibility of the faculty to cycling paths, possibility of safe parking at the faculty building, relative elevation, distance to facilities important to students, etc.). The other variable, gender, is also customary in surveys of habits and opinions, and research has shown that in some countries women use bicycles less (Pucher and Buehler, 2008) and that a higher number of women cyclists indicates a greater sense of safety in cycling in a given city (Baker, 2009). The projected representative sampling encompassed 255 women and 195 men from 30 university faculties and it is proportionate to the number of students of the University of Zagreb given the selected variables (faculty and gender), while the actual sampling differed negligibly. The results obtained were processed by SPSS software, while data analysis and interpretation involved descriptive statistics (shares, arithmetic mean) and testing of statistical significance of the differences between the views of cyclists and non-cyclists made use of the appropriate techniques (t-test and chi-quadrant). MS Excel software was used to visualize the results.

\section{RESULTS}

\section{Student cyclists}

A total of 238 student cyclists were questioned in the survey. Out of the total number of surveyed cyclists, 93 were encompassed in the representative sampling, and 145 in the focused sampling.

The share of student cyclists in the representative sampling was $20.6 \%$. Almost all of those questioned (97.1\%) have bicycles continually at their disposal in Zagreb, while only a small number $(2.9 \%)$ do not.

Student cyclists in Zagreb mostly use their bicycles as a means of transportation: the frequency of use was estimated at an average of 4.32 (ranging from 1 - do not use at all to 5 - use very often) (Fig. 2). According to the average estimation values, walking (3.67) is the second most common form of movement in Zagreb. Experiences from the cities of developed European states have shown that one of the principal features of sustainable cities is the integration of cycling and walking. In the city's territory, this is apparent in the expansion of pedestrian zones and cycling paths, which undoubtedly contributes to the humanization of public space. After bicycles and walking, student cyclists most often use public transit (tramcar and bus) as a means of transport (3.61). This data is not surprising, given that at the time the survey was conducted, travel in the vehicles of ZET (Zagreb's public transit concern) was subsidized for students of the University of Zagreb, so many took advantage of this amenity. The survey has shown that personal automobiles (2.0) and motorcycles (1.22) do not compete with the aforementioned means of transportation. 


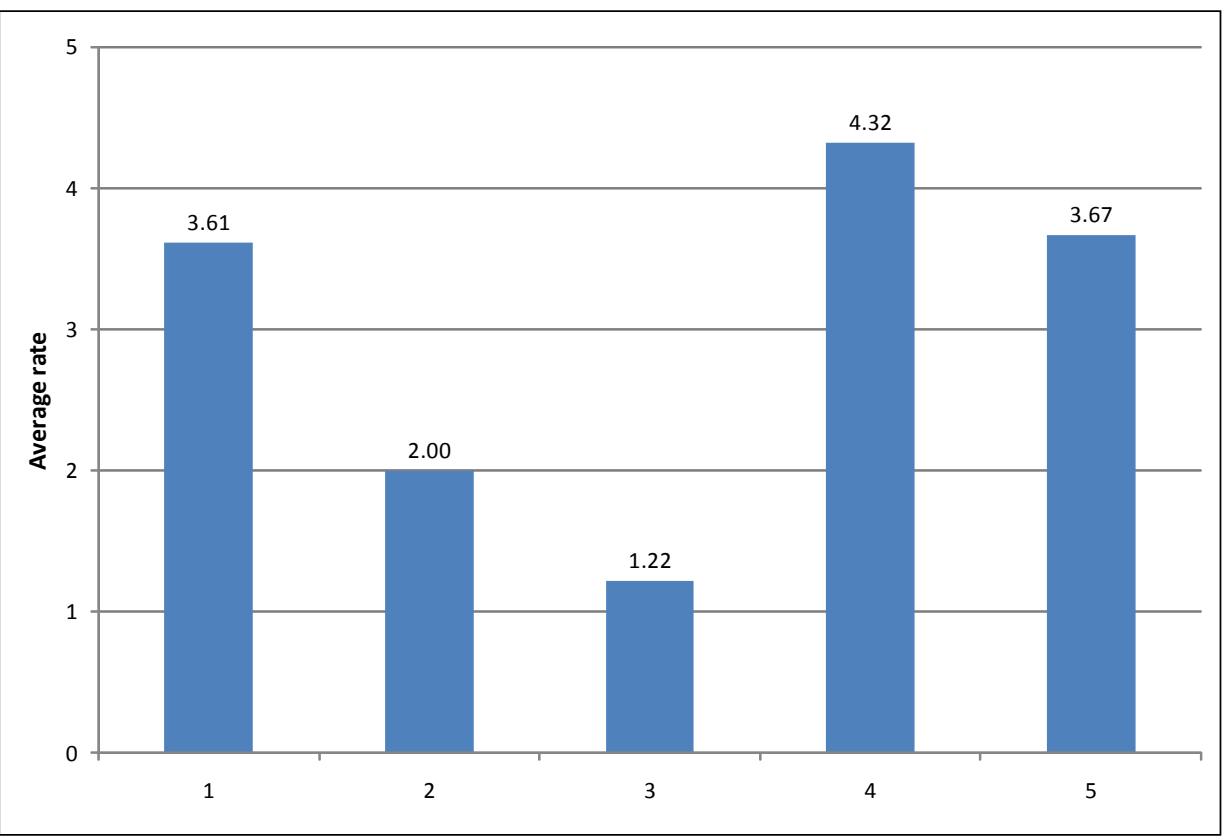

1. Urban public transit, 2. Personal automobile, 3. Motorcycle (including scooters), 4. Bicycle, 5. Walking

Fig. 2 Means of transport used by the student cyclists in Zagreb (1 - do not use at all, 5 - use very often)

Sl. 2. Prijevozna sredstva koja koriste studenti biciklisti u Zagrebu (1-uopće ne koristim, 5-koristim izrazito često)

Student cyclists assessed, with ratings from 1-insufficient to 5-excellent, the existing cycling infrastructure in Zagreb: bikeways (on sidewalks) and bicycle lanes (on carriageways) and bicycle parking. Relatively low average ratings (2.60-2.84) were given to these categories: bikeways and bicycle lanes in the city core, bikeways and bicycle lanes outside of the city core, bicycle parking at dormitories and bicycle parking at university buildings. Student cyclists are the most dissatisfied with the bicycle parking in the city core (2.13) (Fig. 3). Greater insight into the opinions of student cyclists on the cycling infrastructure in Zagreb is provided by data classified by gender. In all five categories of respondents (both women and men), they gave ratings lower than 3.0 (Fig. 4). Both male and female respondents gave low ratings (average rating 2.08 for women and 2.16 for men) to bicycle parking in central Zagreb. The results lead to the conclusion that the cycling infrastructure, despite investment, is poorly developed and that users are unsatisfied with it.

What should the city government do to improve the cycling infrastructure (bikeways and parking) in Zagreb? - this question logically followed after the evaluation of the existing infrastructure. Most respondents (52.3\%) deemed the designation of new bikeways vital to improvement of the cycling infrastructure in the city (Fig. 5). Furthermore, a high number of respondents believed that Zagreb should organize new bicycle parking facilities $(31.3 \%)$. In third place, with a somewhat smaller share, is the view that the existing bikeway network should be upgraded (expanding bikeways where possible, building 
Planning a More Humane City: Student Expectations Concerning Bicycle Use and Transportation in Zagreb

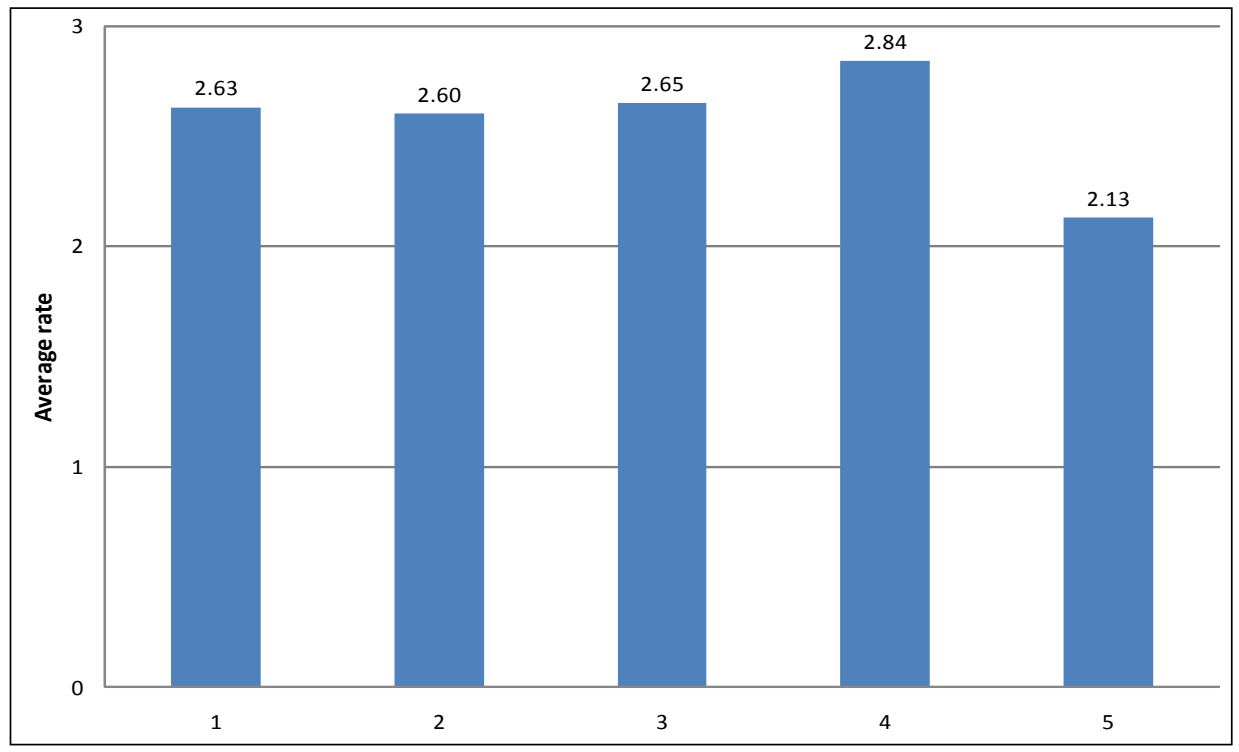

1. Bikeways in city centre, 2. Bikeways outside of city centre, 3. Bicycle parking at dormitories, 4. Bicycle parking at university buildings, 5 . Bicycle parking in city centre

Fig. 3 Average rating of the cycling infrastructure in Zagreb by student cyclists (1 - insufficient, 5 - excellent) Sl. 3. Prosječna ocjena biciklističke infrastrukture u Zagrebu (1 - nedovoljan, 5 - odličan)

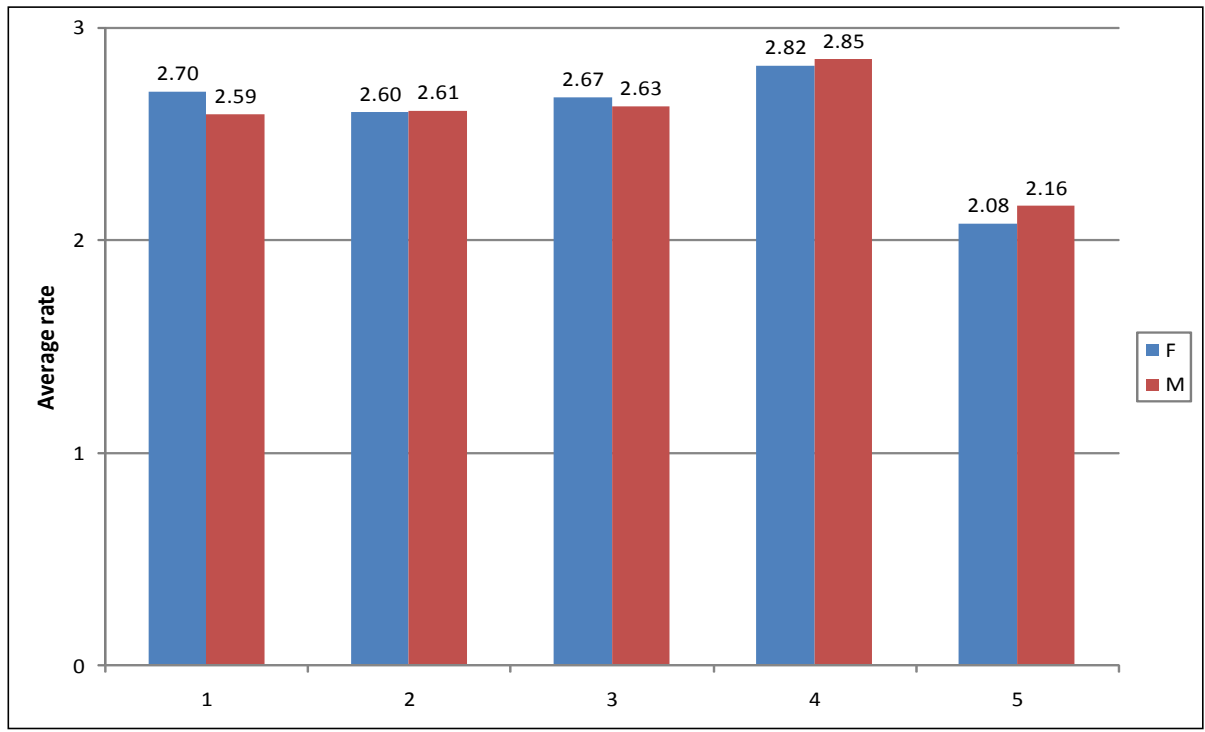

1. Bikeways in city centre, 2. Bikeways outside of city centre, 3. Bicycle parking at dormitories, 4. Bicycle parking at university buildings, 5 . Bicycle parking in city centre

Fig. 4 Average rating of cycling infrastructure based on gender of student cyclists (1 - insufficient, 5 - excellent) Sl. 4. Prosječna ocjena biciklističke infrastrukture prema spolu (1-nedovoljan, 5 -odličan) 
bikeways separate from carriageways and sidewalks, interlinking new and existing bikeways, eliminating obstacles such as waste containers from existing bikeways, prohibiting motor vehicle parking on bikeways, etc.) (26.0\%). The accompanying infrastructure (sidewalks, kerbing, bikeways signs, etc.), which eases the movement of cyclists and other participants in traffic, and also increasing safety, is also deemed important (14.0\%). Almost 11.0 percent of those questioned underlined the problem of safety and the upgrading of existing bikeways. With reference to improvement of the cycling infrastructure in Zagreb, the respondents stressed the importance of locations for the construction of new bikeways, particularly toward and in the city core, and to/from the new university campus in the Borongaj precinct (7.3\%). Also worth mentioning is the location (construction) of new bicycle parking facilities in front of the university buildings and student dormitories $(4.0 \%)$, and the expansion of the existing pedestrian zone was also mentioned as one of the measures in this regard. Although not directly tied to the improvement of the cycling infrastructure, many students believe that the education of all participants in traffic is an important factor (15.3\%). Namely, responsible and conscientious participation in traffic

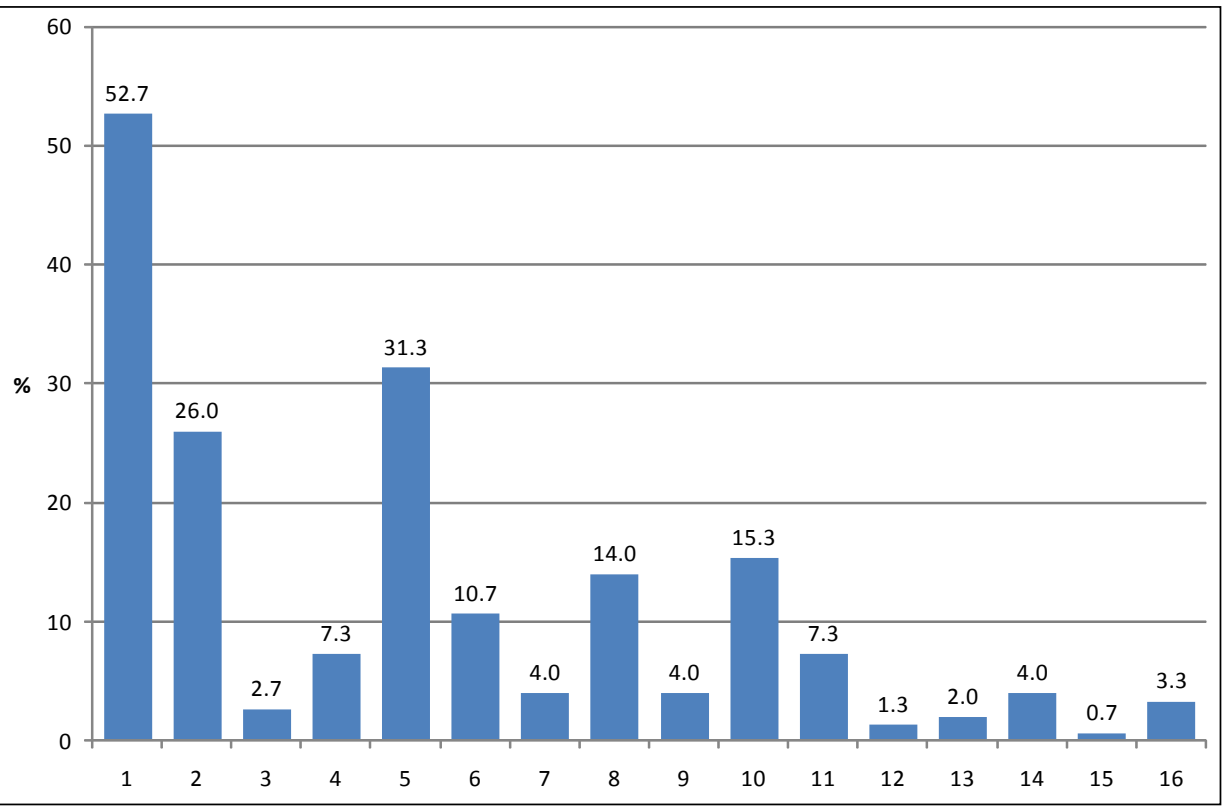

1. Designation of new bikeways, 2. Upgrading of existing bikeways, 3. Networking bikeways, 4. Location of bikeways, 5. Establishment of new bicycle parking, 6 . Increasing safety and upgrading of existing bicycle parking, 7. Location of bicycle parking, 8. Improvement of infrastructure (sidewalks, kerbing, bikeway signs, etc.), 9. Bicycle rentals, 10. Education of participants in traffic, 11. Other, 12. Improvement of cyclist safety in traffic, 13. Development of traffic strategy for Zagreb, 14. Limitation of motor vehicle traffic in Zagreb's (wider) city core, 15. Public involvement, 16. Sanctions

Fig. 5 Opinions (expectations) of student cyclists on what the city government should do to improve the cycling infrastructure (bikeways and parking) in Zagreb (\% of respondents)

Sl. 5. Mišljenje (očekivanja) studenta biciklista o tome što bi gradske vlasti trebale učiniti da unaprijede biciklističku infrastrukturu (staze i parkirališta) u Zagrebu (\% ispitanika) 
and use of the cycling infrastructure in the same vein guarantees quality and safe travel for all participants in traffic. Within the framework of these responses, the respondents provided an entire series of examples of irresponsible and unconscientious behaviour, and a few are here cited as examples: parking in bikeways, streetside restaurant/café terraces which cut into bikeways, etc.

The following question elaborated the initiated topic of the improvement of cycling traffic, but exclusively in the zone which, based on the responses to certain preceding questions, allows for the conclusion that bicycle use is difficult there: the city core. Student cyclists proposed the following measures: designation of new bikeways $(40.3 \%$ of respondents); upgrading of existing bikeways (26.9\%); establishing new bicycle parking $(22.7 \%)$; limitation of motor vehicle traffic $(11.8 \%)$; increasing safety and upgrading of existing bicycle parking and improvement of infrastructure (sidewalks, kerbing, signs on bikeways, etc.) (10.1\%) (Fig. 6).

Since foreign research has shown that the cycling infrastructure is only one of the elements for encouraging the use of bicycles as a means of transport (Pucher et al., 2010),

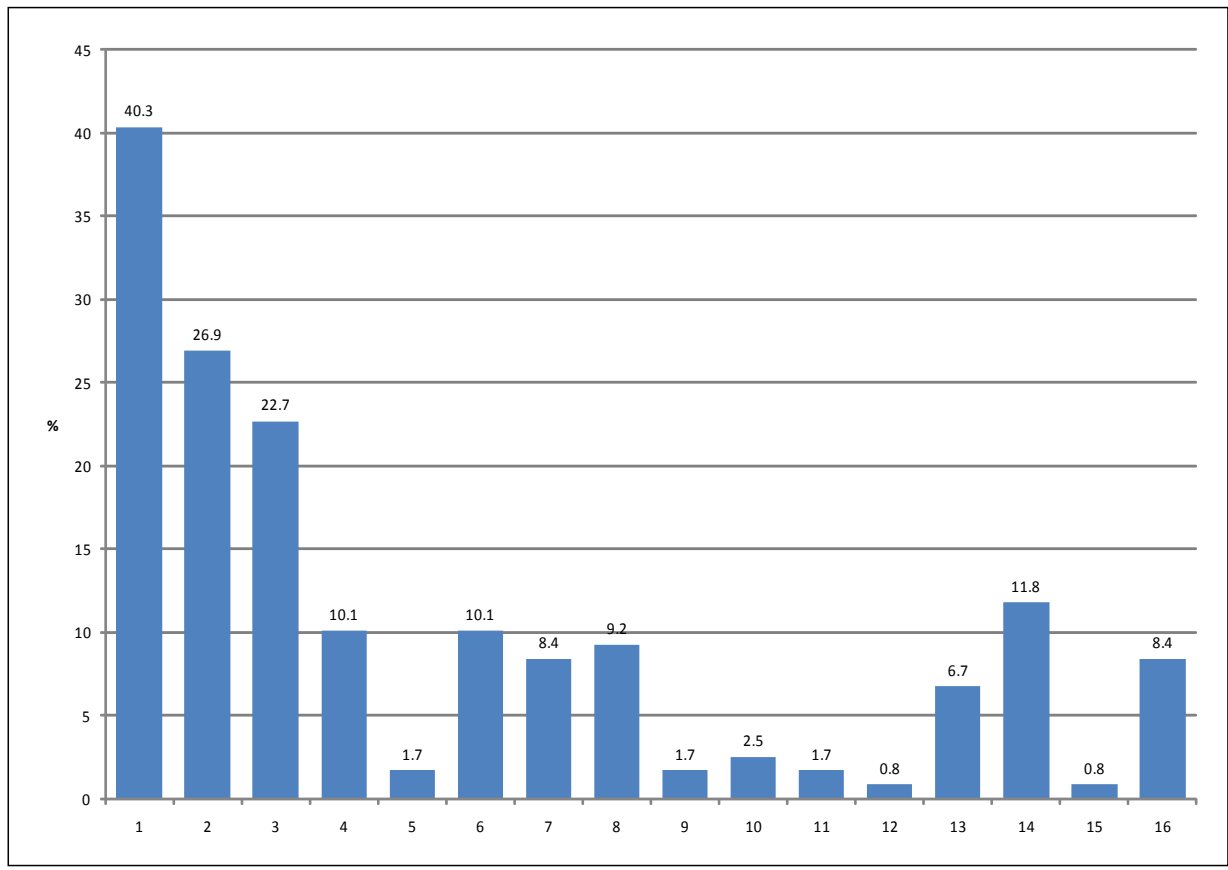

1. Designation of new bikeways, 2. Upgrading of existing bikeways, 3. Establishment of new bicycle parking, 4. Increasing safety and upgrading of existing bicycle parking, 5. Location of bicycle parking, 6. Improvement of infrastructure (sidewalks, kerbing, bikeway signs, etc.), 7. Bicycle rentals, 8. Education of participants in traffic, 9. Publicity, 10. Improvement of cyclist safety in traffic, 11. Enabling bicycle purchases at a discount, 12. Cycling maps, 13. Other, 14. Limitation of motor vehicle traffic in Zagreb's (wider) city core, 15. Sanctions, 16. Traffic etiquette.

Fig. 6 Opinions of student cyclists on easier bicycle use in central Zagreb (\% of respondents)

Sl. 6. Mišljenje studenata biciklista o načinima olakšanog korištenja bicikla u središtu Zagreba (\% ispitanika) 
student cyclists were asked "What should the city government do to encourage greater bicycle use among students in Zagreb?" This topic confirmed the diversity of responses obtained. The primary recommendation made by students was that the city government should enable discounts for students purchasing bicycles (50.4\% of respondents) (Fig. 7). The second recommendation entailed the introduction, based on the example of certain West European cities, of a public bicycle sharing system (bike-share program), with the possibility of lending them to students free of charge (18.9\%). The already emphasized need for construction of new cycling infrastructure was recognized by respondents as the third most important recommendation to the city government $(16.5 \%)$. Out of the remaining recommendations by student cyclists to the Zagreb city government, we shall cite the most important: increased safety and upgrading of existing bicycle parking $(11.8 \%)$; publicity (11.0\%); establishment of new bicycle parking and education of participants in traffic $(10.2 \%)$.

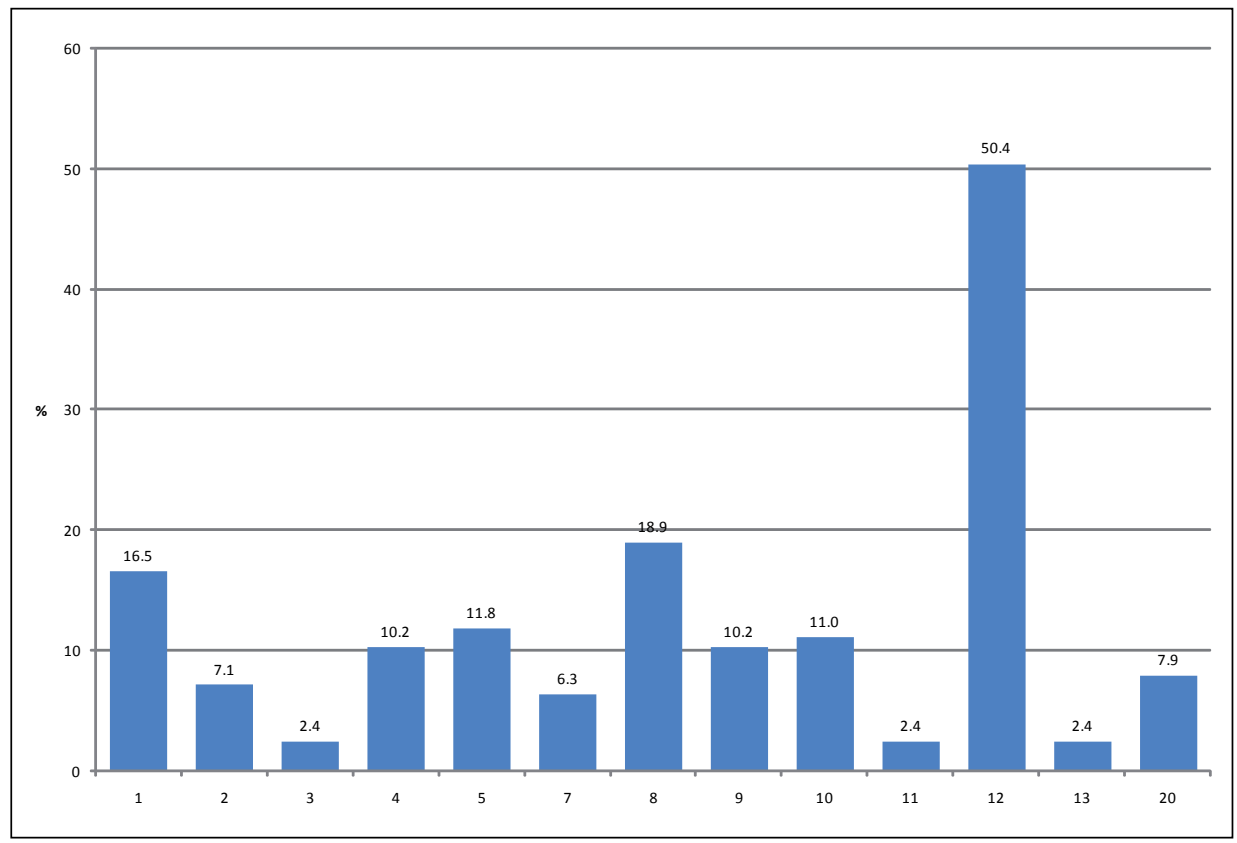

1. Designation of new bikeways, 2. Upgrading of existing bikeways, 3. Networking bikeways, 4. Establishment of new bicycle parking, 5. Increasing safety and upgrading of existing bicycle parking, 7. Improvement of infrastructure (sidewalks, kerbing, bikeway signs, etc.), 8. Bicycle rental (city-owned bicycle system, bikeshare), 9. Education of participants in traffic, 10. Publicity, 11. Improvement of cyclist safety in traffic, 12. Bicycle purchase discounts for students, 13. Cycling maps, 20. Other

Fig. 7 Influence of city government on encouraging greater use of bicycles among student cyclists in Zagreb (\% of respondents)

Sl. 7. Utjecaj gradskih vlasti na poticanje većeg korištenja bicikla među studentima biciklistima u Zagrebu (\% ispitanika) 


\section{Student non-cyclists}

The survey encompassed 359 non-cyclists, meaning students who cycle less than once per month on average, either as a means of transport or as a form of recreation. The share of student non-cyclists in the representative sampling was $79.4 \%$. Out of the 359 non-cyclists, 29 percent of them have their own bicycle or one continually at their disposal in Zagreb.

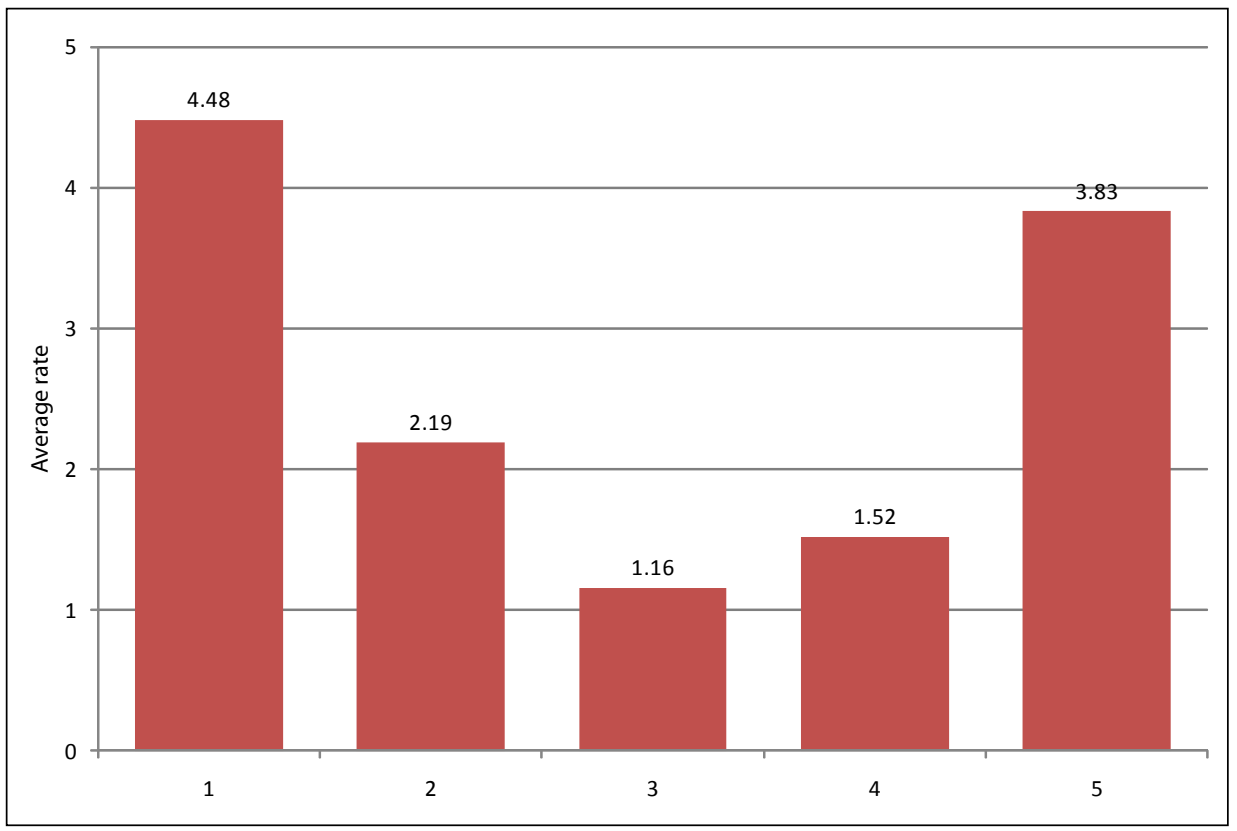

1. Public urban transit (bus and tramcar), 2. Personal automobile, 3. Motorcycle (including scooters), 4. Bicycle, 5. Walk

Fig. 8 Means of transport used by the student non-cyclists in Zagreb (1 - do not use at all, 5 - use quite frequently)

Sl. 8. Prijevozna sredstva koja koriste studenti nebiciklisti u Zagrebu (1 - uopće ne koristim, 5 - koristim izrazito često)

Student non-cyclists in Zagreb most often use public urban transit (tramcar and bus) (average rating 4.48) (Fig. 8). They also often walk (3.83), while use of other means of transportation is considerably more rare.

Student non-cyclists did not respond to queries on the evaluation of the cycling infrastructure nor make recommendations for its improvement, but they were asked to make recommendations to the city government concerning the promotion of bicycle use among students in Zagreb. The primary recommendation made by these students underscored that the city government should subsidize bicycle purchases (27.5\% of students) (Fig. 9). The second, and a very important, recommendation to the city government in encouraging greater bicycle use involved the construction of new bikeways (26.3\%). Out 
of the remaining recommendations, notable is the possibility of a bicycle rental/bike-share system (14.4\%). The safety aspect (12.3\%) and safety and establishment of bicycle parking $(11.9 \%)$ also placed rather highly.

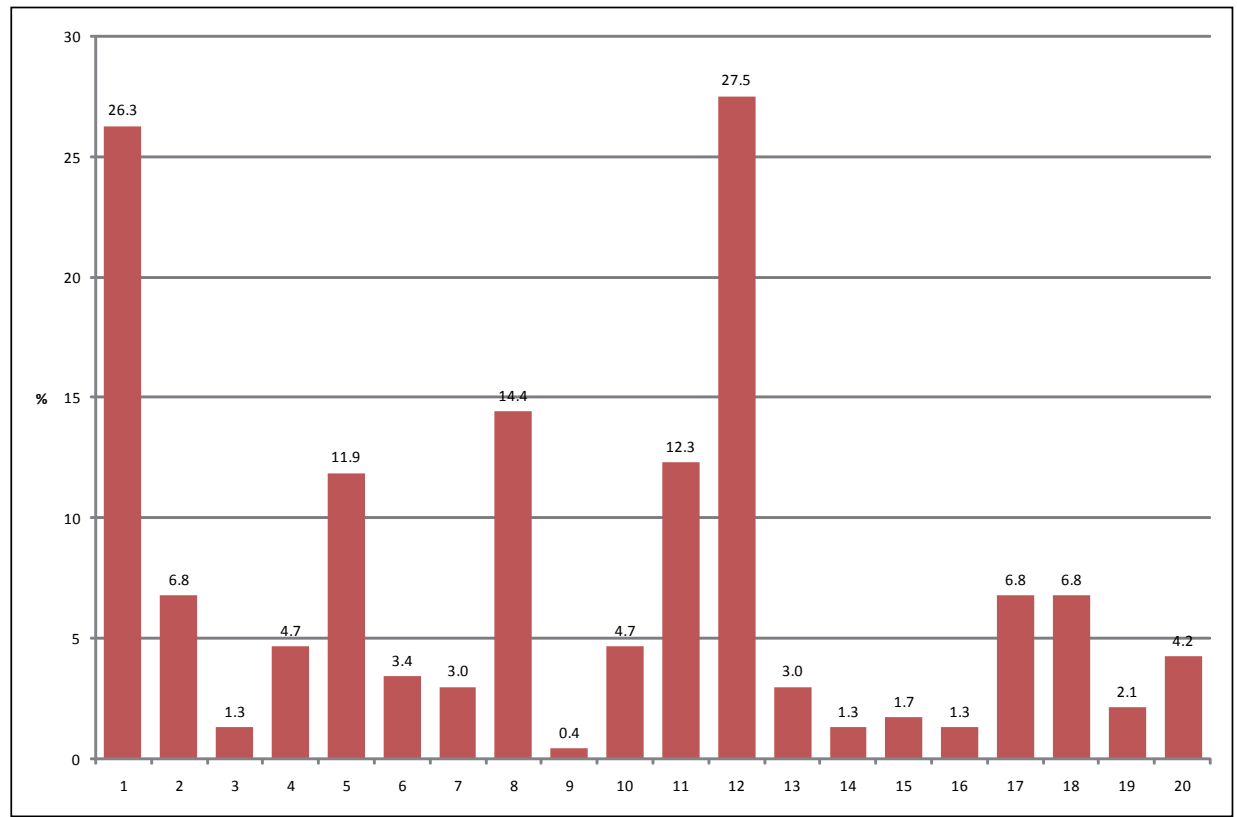

1. New bikeways, 2. Organization of bikeways, 3. Networking of bikeways, 4. New parking, 5. Safety and establishment of parking, 6. Traffic etiquette, 7. Infrastructure (sidewalks, kerbing, bikeway signs, etc.), 8. Rentals (city-owned bicycle system, bike-share), 9. Education, 10. Publicity, 11. Safety, 12. Discount bicycle purchasing, 13. Cycling map, 14. Environmental protection, 15. Motivation, 16. Sanctions, 17. Free bicycles for students, 18. Limitation of motor vehicle traffic, 19. Joint activities, 20. Other

Fig. 9 Influence of city government on encouraging greater use of bicycles among student non-cyclists in Zagreb (\% of respondents)

Sl. 9. Utjecaj gradskih vlasti na poticanje većeg korištenja bicikla među studentima nebiciklistima u Zagrebu (\% ispitanika)

\section{Similarities and differences in the expectations of cyclists and non-cyclists}

Familiarity with the similarities and differences in the habits and expectations of both groups may help in planning the proper activities and the formulation of specific and, for the needs of both groups, more sensitive measures. A certain number of questions were identical in both questionnaires in order to gauge the potential differences in the habits and opinions between cyclists and non-cyclists. The significance of two common questions was hereby tested.

The first pertained to the habits of use of various means of transport in Zagreb. Statistically significant differences were established in the use of public urban transit (bus and tramcar) which are used more by student non-cyclists (4.5) than cyclists (3.6) 
(Tab. 1). As expected, this is primarily because student cyclists very often use bicycles as personal transport (30.3\% of cyclists use bicycles every day to travel to their faculties). Another argument backing this interpretation is that statistically significant differences were ascertained also in bicycle use, which is much more frequent among student cyclists than non-cyclists (1.5) (with an average rating of 4.3, the bicycle is the most used means of transport among student cyclists!).

Tab. 1 What are all the means of transport that you use in Zagreb?

Tab. 1. Kojim se sve prijevoznim sredstvima koristite u Zagrebu?

\begin{tabular}{|l|c|c|c|c|}
\hline \multicolumn{1}{|c|}{ Means of transport } & Student cyclists & Student non-cyclists & $\mathrm{t}$ & $\mathrm{p}$ \\
\hline 1. Urban public transit & 3.61 & 4.48 & 8.60 & 0.000 \\
\hline 2. Personal automobile & 2.00 & 2.19 & 1.69 & 0.092 \\
\hline $\begin{array}{l}\text { 3. Motorcycle } \\
\text { (including scooters) }\end{array}$ & 1.22 & 1.16 & -0.98 & 0.329 \\
\hline 4. Bicycle & 4.32 & 1.52 & -34.82 & 0.000 \\
\hline 5. Walking & 3.67 & 3.83 & 1.66 & 0.098 \\
\hline
\end{tabular}

A common question for which it was methodologically justified to apply testing of statistically significant differences entailed the need for greater bicycle use as a means of transport in Zagreb. Although a very large majority in both researched groups believed that bicycles should be used more as a means of transport in Zagreb $(96.2 \%$ of cyclists and $87.4 \%$ of non-cyclists), a statistically significant difference in their responses was nonetheless ascertained (Tab. 2).

Tab. 2 Do you believe that bicycles should be used more as a means of transport in Zagreb?

Tab. 2. Smatrate li da bi bicikl trebalo više koristiti kao oblik prijevoza u Zagrebu?

\begin{tabular}{|c|c|c|c|c|}
\hline $\mathrm{N}=593$ & Student cyclists & Student non-cyclists & Chi-square & $\mathrm{p}$ \\
\hline Yes & $96.2 \%$ & $87.4 \%$ & 13.495 & 0.001 \\
\hline No & $0.4 \%$ & $2.5 \%$ & & \\
\hline Don't know & $3.4 \%$ & $10.1 \%$ & & \\
\hline
\end{tabular}

Student expectations of the city government concerning the encouragement of greater bicycle use (Fig. 7 and 9 ) point to the conclusion that the most favoured measures regardless of whether the respondents were cyclists or non-cyclists are: discount bicycle purchasing in first place, and among the top five in both groups, the possibility of renting bicycles public bicycle sharing (bike share) system, construction of new cycling infrastructure and increased safety and upgrading of existing bicycle parking. Since these were open-testing questions, the statistical significance of differences was not applied. 


\section{DISCUSSION AND CONCLUSIONS}

The survey of a representative sampling of students of the University of Zagreb established that on average $20.6 \%$ of students use bicycles once monthly at a minimum (except in the colder seasons of the year), either as a means of transport or as a form of recreation. All elements of the existing cycling infrastructure in Zagreb (bikeways, bicycle lanes and bicycle parking) have been evaluated by student cyclists with an average rating of less than 3.0. Students are the least satisfied with parking in the city core, which they gave an average rating of 2.1. The remaining results indicate that students, besides improvement of the cycling infrastructure (bikeway network, bicycle lanes and bicycle parking), expect a series of other activities by the city government: from, for example, specific measures like subsidies to purchase bicycles and implementation of a city-owned bicycle system to those requiring a broad circle of interested parties for implementation - such as measures entailing the education of all participants in traffic.

The recognizable expectations surrounding diverse measures have been confirmed by numerous foreign research projects. Based on the most comprehensive studies known to the authors (Pucher et al., 2010), encompassing analysis of 139 sets of research results the following groups of measures used in cities worldwide may be distinguished: 1. Organization of bicycle lanes and bikeways, 2. Organization of bicycle parking, 3. Adaptation of existing road infrastructure to the needs of cyclists, 4 . Measures to slow and limit motor vehicle traffic, 5 . Infrastructure in the service of promoting bicycle use, 6 . The possibility of renting and returning bicycles at numerous city-wide locations - public bicycle sharing system (bike-share program), 7. Social aspects, publicity and motivation, 8. Traffic school, etiquette and safety, 9. Financial aspects: bicycle purchasing and maintenance, 10. Integration of cycling and pubic urban transport (group of measures not specified based on importance).

In other words, the question of bicycle traffic should be viewed in a context broader than the question of bikeways and bicycle parking. The examples mentioned in the introductory section show that despite climatic and relief conditions, as well as bicycle use traditions, city governments and all parties interested in formulating long-term sustainable urban traffic systems and securing the humanization of space and creating cities to the measure of people have a series of tools at their disposal to achieve these objectives. The consistent application of such tools since the 1970s by cities such as Amsterdam, Copenhagen, Groningen and Münster has yielded very high shares of bicycle use as a means of transport.

Based on the results of the completed survey and a review of the measures taken to increase the share of bicycles as a means of transport in European and world cities, it became apparent that increase in the number of cyclists, both students and citizens in general, in Zagreb demands an entire series of mutually interlocking measures. Given the purpose of this research (support to measures by the city government to double the number of cyclists among the student population in Zagreb), we close this article with proposed activities to be undertaken by the city government and other interested parties.

Preparation of the City of Zagreb Cycling Master Plan, a strategic document containing the long-term goals for the development of the cycling infrastructure in the city 
and all other measures required to increase the share of cyclists, with particular emphasis on the creation of a safe, conducive and pleasant environment for bicycle use as a vital and equally valued means of transport in the city. The preparation and actualization of the Cycling Master Plan would be more effective with the creation of a GIS base of spatial data on the overall cycling infrastructure in the City of Zagreb, which would facilitate more timely and higher-quality maintenance of existing, and planning of new-components of the network, spatial analysis of the relationships between cycling and other traffic networks, etc.

Integration of the most important determinants of the City of Zagreb Cycling Master Plan into the City's strategic physical planning and traffic documents. Bicycle traffic, if truly seen as traffic, and not largely as a form of recreation, must be treated as such in the most important strategic documents of the City of Zagreb. The networking of the existing components of the cycling infrastructure, further development of the network and its integration into an intermodal system of the public urban transit system will not be possible without this step.

Development of the Catalogue of the Cycling Infrastructure Construction Standards (bikeways, bicycle lanes and bicycle parking). The results of the completed research clearly indicate the need for enhancing the quality of bikeways, bicycle lanes and bicycle parking. Even though they differ from country to country, standards governing the width, location and security of bikeways and bicycle lanes on carriageways and sidewalks are an inevitable component of cycling network planning. The Catalogue should contain examples of efficient and secure elements of the cycling infrastructure and possibilities for their application in different urban planning situations.

Formulation of the City of Zagreb Cycling Marketing Plan. Foreign experiences in the promotion of bicycle use, as well as the exceptionally high sums which the automobile industry invests in the promotion of personal motor vehicles, clearly underscore the need for a systematic and serious approach to bicycle promotion.

Ongoing research and validation of results achieved. Research and monitoring of share of cyclists, whether by means of census data, counting of cyclists or surveys, are a vital component of planning and encouraging bicycle use in the city. By providing feedback on the effectiveness of individual measures to increase bicycle use, they make it possible for the city government to act with greater efficiency and financial responsibility.

Further promotion of participatory forms in planning the infrastructure and promoting bicycles as means of transport and recreation. The positive experiences thus far achieved through the involvement of non-governmental organizations, the academic community and the public must be utilized in further activities.

We would like to thank Valerija Kelemen-Pepeonik, M.S., Željka Pavlović and Matija Vuger from the City Strategic Planning and Urban Development Office for their interest, generous assistance and support in the planning and implementation of this research. We would also like to thank Martina Cvitković, Marta Jovanić, Zlatka Matek, Tamara Mihoci, Šime Sušić and Ante Šušnjara, students enrolled at the Faculty of Science, Department of Geography, for participating in the survey. 


\section{NOTES}

1 The city government in Copenhagen launched the planned humanization of the urban zone in the 1960s. During this period, the pedestrian zone in the city centre grew from $15,800 \mathrm{~m}^{2}$ (1962) to $99,700 \mathrm{~m}^{2}$ (2005). The number of parking spaces in the city centre also declined. In the mid-1990s, there were 3,100 parking spaces, while in 2005 this figure declined to 2,720. At the city-wide level, in the latter half of the twentieth century, the number of organized and constructed bikeways increased $(1950-150 \mathrm{~km}, 2005-343 \mathrm{~km})$, while in many streets, particularly in the city centre, speed limits were instituted, so that travel by bicycle on them became freer and safer (Gehl et al., 2006). These improvements in the quality of life and the humanization of space were also reflected in the components of the city's physical structure, particularly in its core area. Thus, for example, the commercial and hospitality functions were strengthened. It is particularly important to stress that during this period, higher quality was also registered in the housing stock, and this was reflected in the reurbanization of Copenhagen's central zone. In the 1995-2005 period, the number of residents increased from 6,800 to 7,600 . The morphological humanization of the city has also been noted: housing and commercial buildings, parks, promenades, etc. are being restored, and sometimes even newly constructed (Gehl et al., 2006; Gehl, 2010).

2 Bikeways and bicycle lanes may be planned and constructed separately from streets as independent surfaces within the thoroughfare's profile and as a component of the carriageway or pedestrian way designated with traffic signs. Bikeways and bicycle lanes must be planned and built along routes indicated in cartographic projections, and they may be built on other surfaces as well. The minimum width of a bikeway or bicycle lane is $1.0 \mathrm{~m}$, and $1.6 \mathrm{~m}$ for two-way traffic. If a bikeway or bicycle lane is immediately adjacent to a carriageway, an additional safety width of $0.75 \mathrm{~m}$ is added. Exceptionally, the safety width is not required if the street has a motor vehicle speed limit of $50 \mathrm{~km} / \mathrm{h}$. The lengthwise gradient of a bikeway or bicycle lane cannot be greater than $8 \%$ (Article 41 of the Decision on Ratification of the City of Zagreb Master Plan).

3 These data-bases were examined: Hrčak-Portal of Croatian scholarly/scientific journals (http://hrcak.srce.hr) and the Croatian science bibliography (http://bib.irb.hr).

4 These were the conferences "Traffic Problems in the City of Zagreb" organized by the Croatian Academy of Arts and Science in 2006, and "Development of Zagreb" organized by the Zagreb City Executive Council and the Croatian Engineering Association in 2008. The complete references are listed in the source list.

5 In the census questionnaire for 2011, question 38 reads: Means of transport to work or school, and one of the 13 responses offered is bicycle. It is possible to select a maximum of two of these 13 options. The intended respondents are persons who work or are attending school (source: National Statistics Bureau, http://www. dzs.hr).

6 Three faculties of the University of Zagreb are located outside of it: Geotechnical Engineering, Metallurgy and Organization and Computer Science. Their students were not encompassed in the sampling because they do not study in Zagreb. Three questionnaires were invalid.

\section{REFERENCES}

Bedenko, V., 2008: Održiva mobilnost za kvalitetu života u gradu, in: Radić, J. (ed.), Razvitak Zagreba, Zbornik radova, Second HDGK d.o.o., Zagreb, 117-122

Bertić, I., 1994: Zagreb - metropola Republike Hrvatske, Geografski horizont 40(2), 1-17

Blanco, H., Alberti, M., Forsyth, A., Krizek K.J., Rodríguez D.A., Talen E., Ellis C., 2009: Hot, congested, crowded and diverse: Emerging research agendas in planning, Progress in Planning 71, 153-205

Božičević, J. (ed)., 2006: Prometna problematika Grada Zagreba, Zbornik radova, Hrvatska akademija znanosti i umjetnosti, Znanstveno vijeće za promet, Zagreb 
Planning a More Humane City: Student Expectations Concerning Bicycle Use and Transportation in Zagreb

Buehler, R., Pucher, J., 2010: Cycling to Sustainability in Amsterdam, Sustain: A Journal of Environmental and Sustainability Issues 21, 36-40

Dragičević, V., Rukavina, T., Korlaet, Ž., 2006: Prilog ocjeni stanja zagađenja bukom od cestovnog prometa, in: Božičević, J. (ed.), Prometna problematika Grada Zagreba, Zbornik radova, Hrvatska akademija znanosti i umjetnosti, Znanstveno vijeće za promet, Zagreb, 169-178

Gatersleben, B., Haddad, H., 2010: Who is the typical bicyclist?, Transportation Research Part F 13, 41-48

Gehl, J., 2010: Cities for People, Island Press, Washington

Gehl, J., Gemzøe, L., Kirknæs, S., Søndergaard, B. S., 2006: New City Life, The Danish Architectural Press, Copenhagen

Golubić, J., Kolar, V., 2006: Ekološki aspekti optimizacije prometa na raskrižjima u gradu Zagrebu, in: Božičević, J. (ed.), Prometna problematika Grada Zagreba, Zbornik radova, Hrvatska akademija znanosti i umjetnosti, Znanstveno vijeće za promet, Zagreb, 157-168

Halgota, V., 2010: Planiranje gradskog prometa: javni bicikli kao dio prometnog identiteta Zagreba, Diskrepancija 10(14-15), 61-71

Missoni, E., Kern, J.. 2007: Schoolchildren and Bicycle Helmet Use in Croatia, Društvena istraživanja 16(3), 577-587

Nankervis, M., 1999: The efect of weather and climate on bicycle commuting, Transportation Research Part A $33,417-431$

Plaut, P. O., 2005: Non-motorized commuting in the US, Transportation Research Part D 10, 347-356

Pološki, D., Nikolić, A., Njegovec, M., 2008: Redukcija prometa u centru Zagreba, in: Radić, J. (ed.), Razvitak Zagreba, Zbornik radova, Second HDGK d.o.o., Zagreb, 371-374

Pucher, J., Buehler R., 2006: Why Canadians cycle more than Americans: A comparative analysis of bicycling trends and policies, Transport Policy 13, 265-279

Pucher, J., Buehler R., 2008: Making Cycling Irresistible: Lessons from The Netherlands, Denmark and Germany, Transport Reviews 28(4), 495-528

Pucher, J., Dill, J., Handy, S., 2010: Infrastructure, programs, and policies to increase bicycling: An international review, Preventive Medicine 50, 106-125

Radić, J. (ed.), 2008: Razvitak Zagreba, Zbornik radova, Second HDGK d.o.o., Zagreb

Rybarczyk G., Wu C., 2010: Bicycle facility planning using GIS and multi-criteria decision analysis, Applied Geography 30, 282-293

\section{SOURCES}

Baker, L., 2009: How to Get More Bicyclists on the Road, Scientific American, http:// www.scientificamerican. com/article.cfm?id=getting-more-bicyclists-on-the-road (15.1.2011.)

Biciklist, Hrvatski jezični portal, http://hjp.srce.hr/, (02.2.2011.)

Copenhagenize.com - Building better bicycle cultures, http://www.copenhagenize.com, (18.1.2011.)

Cycling in London, Final report, Prepared for Transport for London (2008), http://www. tfl.gov.uk/assets/downloads/businessandpartners/cycling-in-london-final-october-2008.pdf, (20.2.2011.), 1-77

Odluka o donošenju Generalnoga urbanističkog plana grada Zagreba 2007., Službeni glasnik Grada Zagreba 16/2007,

Službene stranice Grada Zagreba, http://www.zagreb.hr/default.aspx?id=1900 (12.3.2011.) 
Prometna studija Grada Zagreba, 1999, Službene stranice Grada Zagreba, http://www. zagreb.hr/default. aspx?id=664 (15.2.2011.)

Zelena akcija, 2010: Analiza zagrebačkog prometnog sustava i preporuke za njegovo poboljšanje, 1-18

\section{STATISTICAL SOURCES}

1. Statistički ljetopis Zagreba 2000., Gradski zavod za planiranje razvoja grada i zaštitu okoliša, Odjel za statistiku, 2001., Zagreb.

2. Statistički ljetopis grada Zagreba 2005., Gradski zavod za prostorno uređenje, Odjel za statistiku, 2005., Zagreb.

3. Statistički ljetopis Zagreba 2009., Gradski ured za strategijsko planiranje i razvoj grada, Odjel za statistiku, 2009., Zagreb.

4. Prijevoz i skladištenje - tromjesečno priopćenje 1-4, Gradski ured za strategijsko planiranje i razvoj grada, Odjel za statistiku, 2009., Zagreb.

Received (Primljeno): $2011-03$ - 30

Accepted (Prihvaćeno): $2011-04-18$

Aleksandar Lukić, PhD, Assistant Professor University of Zagreb, Faculty of Science Department of Geography Marulićev trg 19/II, 10000 Zagreb alukic@geog.pmf.hr

Vedran Prelogović, PhD, Assistant Professor University of Zagreb, Faculty of Science Department of Geography Marulićev trg 19/II, 10000 Zagreb vprelogo@geog.pmf.hr

\section{Stanko Rihtar}

Institut of Social Sciences Ivo Pilar Marulićev trg 19/I, 10000 Zagreb

Stanko.Rihtar@pilar.hr 